\title{
German Poetry in African Languages: The Translation of Selected German Poems From an Intercultural Perspective
}

\author{
Louis Ndong \\ University Cheikh Anta Diop, Dakar, Senegal
}

\begin{abstract}
The article deals with the translation of German poetry into Wolof and is based on Tamsir Annes's translation of German poems under the title Téere-Woy yi/ Das Buch der Lieder. My purpose in this paper is to answer the question of how elements of the vocabulary of sciences (literature and philosophy) as well as cultural specific items are rendered in the Wolof target text. Therefore, in this work, I explore methods and strategies of translation like borrowings, paraphrases, and analyze furthermore some differences noticeable in the translation of some poems at the cultural level. These analysis-steps enable the investigation of, contextually, the central issue of "cultural translatability” and the reception of translation of European poetry into African languages in general and German poetry into Wolof in particular. The article also focuses on the importance of the reception of German poetry in Wolof as a means of intercultural communication between German and Wolof-speaking countries but as means to develop African languages like Wolof in which the translation of the selected poems has been operated.
\end{abstract}

Keywords: translation, poetry, cultural, strategies, intercultural communication

\section{Introduction}

More and more African Literatures are written in or translated into African languages. Some African authors even write between and/or in two languages: the former colonial one and their mother tongue. The postcolonial debate around the issue of translation of African literature written in European languages into other European languages is also obviously shifted onto other dimensions including African languages as source or target languages. Quite rarely do we see European literature especially from German speaking areas translated into African languages. Therefore, in this paper I will be mostly interested in the translation of German poems into an African language, in this case Wolof. The corpus is based on poems of authors from the German literary epochs like classic translated and/or readapted by the Senegalese Tamsir Anne. As many works on poetry translation focus on formal features of language such as rhyme, rhythm, pun etc., the issue will not be central in the framework of this work. Its main objective is rather to explore and emphasize methods and strategies in relation with the translation of selected poems from an intercultural perspective. The following two central questions will serve as a pillar of this article to meet the above-mentioned objective.

Through which procedures are the linguistic and cultural specific items translated from German into Wolof? Which difficulties of reception of the Wolof-translated version can consequently be observed at the qualitative as well as quantitative level?

Louis Ndong, Lecturer, Department of German Studies, Faculty of Language and Social Sciences, University Cheikh Anta Diop, Dakar. 
In order to answer to these questions, I will first analyze how the different transposition procedures (borrowing, paraphrases and so on) are noticeable in the use of Wolof as target language in the translated version before I point out significant differences between the source text and the target text. Last but not least I will discuss reception issue in relation with the Wolof translated version.

\section{Transferences or Borrowings}

In the field of translation studies in an African context, there is a great debate on the translatability of some items of European languages into African languages. Our purpose in this article is not to discuss this issue. I will rather focus on the strategy of borrowing which in some regards enables the facing up of the difficulty to translate some source language items. Such a procedure for the translation of some selected poems, "refers to a case where a word or an expression is taken from the SL and used in the TL, but in a 'naturalized' form, that is, it is made to conform to the rules of grammar or pronunciation of the TL” (Zakhir, 2008), can be observed already in the translation of the editorial or the introduction of the authors that precedes their poems. We have some examples below:

$\begin{array}{ll}\text { Source text (ST) } & \text { Target text (TT) } \\ \text { Philosophie: } & \text { filosofi (Anne, 2011, p. 7) } \\ \text { Ingenieur: } & \text { enseñëër (Anne. 2011, p. 31) } \\ \text { Romantik: } & \text { romantic (Anne, 2011, p. 31) }\end{array}$

The words of the target text (the Wolof version) are in fact French, but they are commonly used in speeches given in Wolof with a lens of orthographic modification or phonetic adaptation. The use of this strategy shows how the Wolof is in some regards influenced by the French, especially when it comes to expressing vocabulary of sciences. Wolof graphemes are in general based on phonetic values of Latin alphabet which is used for French as well. "Philosophie" or "Romantik" refers to words many people in Senegal are mostly faced the first time they come to French school; they are linked to subjects of school-like "literature" or "philosophy". These borrowings in form of analogy do not obviously illustrate the difficulty to render into African languages words related to education, but show rather the hybridity that characterizes the use of such vocabulary in Wolof which, from a sociolinguistic perspective, is very influenced by the French.

The borrowing as procedure can also be observed in the translation of many poems. It is the case in the example of "Dialektik" (Anne, 2011, p. 47) (dialectic) which is rendered through "jalektik". The word, which is rooted in Greece philosophy, became, and is up to now, central to Western thought. It is not usual in Wolof, since the latter mostly functions as language of every day oral communication especially in interethnic communication and not as language of instruction like French. In speeches made in Wolof, there is a tendency to use vocabulary related to sciences in the same way as they are expressed in French. Because of the closeness between French and German as Indo-European languages, the borrowing in the German translation does not supposedly appear foreign for Senegalese readers. The French word for "Dialektik" is moreover "dialectique". The transposition of the word in the Wolof version through "dialektik" is therefore not only closed to the German target language but also to the French as official language in the source language community. This makes the understanding of the word and the text more fluent for the target audience. Hence, in the text we do not only perceive the traces of the German source language, but also the diglossic situation between Wolof, the 
language of interethnic communication in Senegal, and French, the language of the former colonial power France.

The particularity of borrowings here is that the words as they are used in the target-text are in fact nowadays mostly considered as elements belonging to the Wolof in view of the very close relationship between French and Wolof as two central languages of the same community. The Wolof itself gets enriched with elements of the French in such a way that it is almost possible to express much French elements that might be very rooted in French or western cultures without great risk to be unfaithful.

But these considerations are not true for other borrowings in other examples, where the target text suffers less the influence of French language. In such cases, we have examples of the translation of geographic places. In Heinrich Heine’s poem "Die Heimkehrt” (Anne, 2011, p. 22) (“Ñibi sa réew”), the noun "Rhein”, that corresponds to "the Rhine", which is a famous river in Francfort in Germany is translated by "Rayin" and the expression "Die Lorerei" through "Lorelaay". In the first example the borrowing or transposition concerns a very famous river in Germany. The adapted word ("Rayn"), which is geographically rooted and not usual in Wolof gives the target text a kind of foreignness despite its orthographic and phonetic adaptation. A good method could have been to borrow without any modification or adaptation since we have to do with geographic matters which are mostly considered as "invariants" in case they do not have lexical equivalents. But the objective of the translator could have consisted of trying to adapt the noun to the Wolof pronunciation, to make the reading of the German words easier.

The same is true for "Die Lorelei" in the same poem which is rendered with "Lorelaay"1. The word expresses a place of the Middle Ages and has an epic character; it reflects thematically the romantic idea of melancholia and was used for the first time by the German poet Clemens Brentanno. This was an inspiration for German poets like Eischendorff, Otto von Loeben and Heinrich Heine as well. The latter puts it in relation with a beautiful mermaid referring to the sipper of the Rhine charms like a siren. The word and the legend that is behind is therefore very rooted in the Greek mythology as well as in German literature; it has become at the same time a well-known place of interest in Germany. But through the simple use of borrowing without any paratextual notes, the Wolof-speaking audience does not obviously have the opportunity to get to know and appreciate all these features behind the word and its relevance in German literature. Then notes and additions enable better consideration of the target-text-audience in a way that transmits in a more explicative manner the message of the source-text. In the following, we will be mostly interested in the use of these procedures of additions and notes in the translated version of the selected German poems.

\section{Some Additions and Notes in the Translated Version}

Central for this section is the question of the extent to which additions in translation contribute (or not) to a better understanding of source culture specificities.

\footnotetext{
${ }^{1}$ [T] he Loreley rock is a 194-metre-high slate cliff towering above the narrowest point of the Rhine near St. Goarshausen. It became famous for the tale of Loreley, a beautiful but melancholy siren who would sit on the rock and sing as she combed her golden hair. Her beauty and beguiling song distracted passing sailors from the strong currents and their ships smashed to pieces against the rocks. Today, the Loreley is a magnet for tourists from all over the world. In the Loreley visitor centre, an interactive exhibition tells you everything you need to know about the region. The Upper Middle Rhine Valley became a UNESCO World

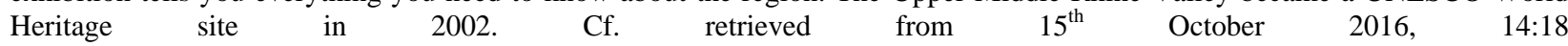
http://www.wanderlust.co.uk/planatrip/inspire-me/lists/top-10-sights-and-attractions-in-germany.
} 
Additions are often used in translation to overcome "untranslatability" or difficulties to translate some source-text-items. But it is interestingly not the case in the translation of some poems. On pages 8 and 9 (Anne, 2011), we have for example in the poem of Johan Wolfgang von Goethe "Der Adler und die Taube":

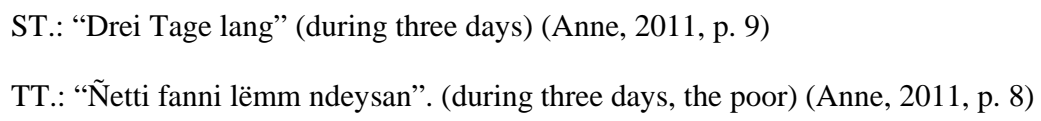

The word "ndeysaan" which expresses compassion is used in the same page of the Wolof version as addition in many passages. This procedure is visible in other passages on the same pages:

\section{ST.: Drei lange, lange Nächte lang \\ TT.: Ñetti guddi ndeysaan}

In the same poem, the use of "Ndeysaan" as added element is noticeable 5 times. The term "ndeysaan" is very often used in Wolof and it is not even rare to find it in many Senegalese literary texts written in French as used by a protagonist to express empathy ${ }^{2}$. This empathy is expressed in the context of the used method of translation in our examples.

Obviously the intention of the translator was not to be faithful to the original, but rather to domesticate the target text. As already emphasized, these additions are not due to the fact that some words are not translatable into Wolof in such a way that they have to be paraphrased. The added elements are close to the ideas of the literary movement of the classic that was characterized by ideas of tolerance and humanity. In this sense, one can say that it contributes to accentuating the target culture to the detriment of the source one. At the same time, the additions enable a better understanding of particularities of the literary epoch in which the original text is rooted.

In the translation of many literary texts, we can find footnotes. One of the advantages of literary translation lies moreover on the possibility to resort to notes to explain if necessary the meaning of cultural specific or difficult translatable items. This method is used in the translation of some of the poems.

In Friedrich Rückehrt's poem Die Alten und die Jungen, the word "Parnasse" (Anne, 2011, p. 41) is translated through "Parnaas" and also explained in a footnote "Dunmag la bu nekk ca réewum Gerek te ñu jàpp na foofee la Yàllay taalifkat ak xaralakat yi fekk baax” (Anne, 2011, p. 40). The footnote underlies the importance of the explained place as a mountain inspiring muse. It makes understanding the idea of muse, which was dedicated to Apollo in Greek Mythology. The word plunges the reader therefore into the Greek philosophy which influence on German philosophy as well as literature is moreover appreciable.

Another word explained in a note is "Mohr" (Anne, 2011, p. 40) in the same poem with "Noonu lañu daan dàkkentale nit ku ñuul ak naar yenn saa yi làkku alma jamono yu njëkk ya”. This explanation comes back to the meaning of the term from a historical perspective as referring to "black person" or "Moor". But one must point out the fact that the term as such is nowadays negative characterized and almost used no more. The footnote does not therefore point out the negative connection of it and rather focuses its meaning in its historical context. An interesting question to raise in this sense would be how to manage discrepancies between the meaning of the described phenomenon in the time of the production of the original text and its reception in regard to the actual potential target public.

${ }^{2}$ It is very common in the literary work of the Senegalese author Ousmane Sembène. 


\section{Paraphrases}

The paraphrase is an often used translation procedure to overcome untranslatability or the difficulty to render some cultural specific elements of the source language. It tries to make the target text understood for the target public. One of the main problems related to translation in general is that some words used in the original version do not have equivalents in the target language because they refer to things that do not exist in the target culture. One speaks then mostly about "cultural untranslatability", what most leads to "lost in translation". The more the cultures and languages are far from each other, the more we have problems of translation. Thus, translating between two European languages or between two African ones can be supposed to be less problematic than between European and African languages.

In Goethe’s poem Das Göttliche (Anne, 2011, p. 14), the word "Hagel” ("hail”) is translated through a paraphrase "taw-donju-sedd" (a kind of "cold-squall-rain”). This item corresponds in a word by word translation into English to "raining of cold grain". The expression provides an understanding of the meant idea in the original. The worship of nature in Goethe's poem, which is one of the main features of the epochal context in which his poem was produced, is a very central aspect to be understood, in order to situate contextually the poem. Das Göttliche is a kind of lyrical classic poetry. The description of nature is very pregnant and part of the features that characterized the classic epoch. It is put here into an African context in which the described phenomenon is also emphasized. A similar example can be observed in the translation of "Schnee" (Anne, 2011, p. 52) (snow) by "pëndëxu-sedd" (powder of coldness) in the following extract:

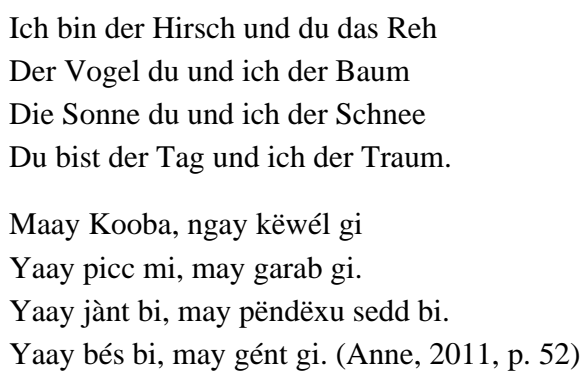

In the context, the translation of "Schnee" through "pëndëxu-sedd" (powder of coldness) points out the opposition as well as complementariness in love symbolized through the expressed elements of nature. The differences between the original and the target text are also not so significant, at least not as in the examples we will analyze in the next section dedicated to entropies between the source and the target text.

\section{Particularities and Significant Differences Between Originals and Translations}

A question raised often, when it comes to translation in general and translation of literary texts in particular, is related to the used method. There is an opposition between two possible alternatives: either a source-culture-oriented, or a target culture-oriented-method:

"Entweder der Übersetzer läßt den Schriftsteller möglichst in Ruhe und bewegt den Leser ihm entgegen; oder er lässt den Leser möglichst in Ruhe und bewegt den Schriftsteller ihm entgegen.” (Schleiermacher, 1963, p. 47).

Let us consider the following extract:

Triffst du im Garten hervor, So bist du die Rose der Rosen, 
Lilie der Lilien zugleich.

Soo juuxee ci tool bi

Die tóor-tóoru tóor-tóor yi (Anne, 2011, p. 17)

In the poem there are many references of natural elements like the sun, moon, star etc. ("Sonne", "Mond", "Gestirn" etc.). The poem illustrates the romantic idea of love which is linked to nature as motif of the Romantic epoch. The use of "Garten" ("garden") in the above-mentioned extract is in this sense symptomatic. But "Garten” is translated by “tool” (Feld), "Rose” by “tóor-tóor” (flower), but "Lilie” (lily) is not translated at all. "Garten” is translated here through a procedure of cultural adaptation, "Rose” through a generalization and "Lilie" was omitted. The use of these different translation procedures is due to the lack of lexical equivalents of the source-text-items in the target language. But through the procedure, many aspects that are specific to the motif of the poem are lost. The word "tool" ("field") has in the target language the connotation of hard rural working whereas "tóor-tóor" would refer in this context to blossoming as a result of the process of making fruits by trees. Thus, the translation does not point out the beauty expressed in the source text and metaphor through the parallelism between a woman and a flower, which is in terms of style and esthetics nevertheless very symbolic.

The title of one of Goethe's poems is Gretchen am Spinnrad (Gretchen at the spinning wheel). The passage is already to be found in Goethe's Faust (Part One, Scene 15) (Anne, 2011, p. 13) and is treated again by Franz Schubert in his song in the $19^{\text {th }}$ century. However, the expression as title of Goethe's poem has been eliminated in the translation into Wolof. Instead of it, one has as a title "Sama jàmm jeex na". This is nothing else then the first verse of the poem (Meine Ruh is hin). Through the omitting strategy of the translator, there is also an aspect of German literature that is lost and which is namely linked to the hypertextual relationship to already existing texts from the German literature and arts in general. At the stylistic and esthetic level, one has the changes of the poem from quatrain into tercet. One can argue that this procedure does not meet the objective of translation as defined by Eugene Nida, which "consists in reproducing in the receptor language the closest natural equivalent of the source text message firstly in terms of meaning, secondly in terms of style" (Greimer, 2004, p. 13). Kollers idea of "text-normative equivalent" as refereeing to equivalence that is in accordance of the genre or the specificities of the genre of the source (Lederer, 1994, p. 64) but has therefore not been taken into consideration.

In Bertolt Brechts poem Lob des Lernens ("Bàkkub njàng”) in which the necessity of learning is stressed, the term "Rechnung” (Anne, 2011, p. 46) (bill) is translated by "kayit bi” ("the paper”).

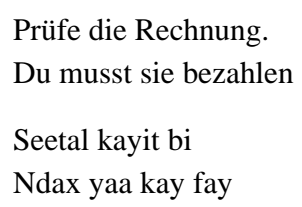

This is a kind of generalization that does not bring precision. It would be difficult to find a precise word in Wolof that can render faithfully the idea expressed by the word German "Rechnung" used in a globalized context of paying. In oral traditional societies, the process of buying and paying is mostly characterized by a simple exchange of words and lies habitually on confidence. Therefore the use of bill is not common in commerce transactions. This explains the lack of correspondent of "Rechnung" ("bill”) in the Wolof language and therefore the use of the method of generalization. However, the word "kayit" as translation of "Rechnung" 
might be contextually understood as a paper to be bought and not as a bill to be paid. The item is of course not German specific, but its translation shows discrepancies between tradition and modernity which might be reflected in the translation of literary texts from European into African languages.

In the next example from Goethe Buch der Sprüche ("Téere-léebuyi”), we have a difference in the translation at the cultural level. The word "Weib” ("women”) is translated by "jabar" ("wife”).

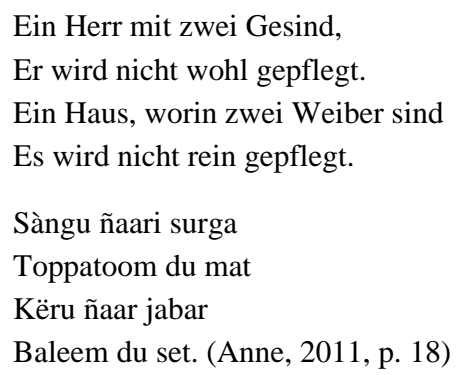

This extract points out the idea of sufficiency as value of human being. In the two last verses, the author emphasizes this idea by using the noun "weiber" what in the literal senses could mean: there is no need to have two women in a house to make it clean. The Wolof version rather uses the word "jabar" ("wifes") instead of "jigeen" (woman), and this automatically raises the issue of polygamy which is very common in the target-text-society. But the target text seems to criticize or to focus more on the phenomenon of polygamy and does not point out suitably the meant idea of sufficiency. In any case, the target audience could in this sense be led to think that polygamy is or was characteristic of Western or German society especially in the period in which the text has been produced. This matter is linked to the problem of reception which is also central in translation matters. In the following, we will come back to this issue and focus on the significance of the translation of the selected poems as cultural transfer beyond languages barriers.

\section{Reception Issues}

Eine lebendige Sprache ist mit einer Pflanze vergleichbar: pflegt man sie, gedeiht sie und wächst prächtig. Dies setzt ebenso den Zugang zu breitem Wissen wie auch die Übersetzung diverser Kulturen voraus. (Anne, 2011, p. 11)

One of the points of view which legitimate the act of translation starts from the fact that translation is intended to people who do not understand the original text: "Une traduction est destinée à ceux qui ne comprennent pas l’original. Sinon, pourquoi diable traduirait-on?” (Berman, 2008, p. 51). "Translations are typically addressed to recipients who themselves have no access to the original language and hence to the original utterance or text” (Hermans \& Koller, 2004, p. 24). Considering this point of view does not only equal the investigation of the methods of translation, but it also enables more to transmit the features of the original text. It invites to think about the significant issue of reception of translated literary texts as well. Through translation, European literary works can be made accessible in African languages in General and in Wolof in the case of our corpus. The translator of the selected poems himselves emphasizes:

Alle Autoren, deren Gedichte hier ausgewählt wurden—sei es die von Goethe, Heine, Hesse oder anderen-sind schon längst weitbekannt. Ihre Werke wurden zudem in nahezu alle lebendigen Sprachen der Welt übersetzt. Insofern ist es angebracht, dass dieses breite und vielfältige Schaffen ebenfalls in den Hauptsprachen Afrikas zugänglich wird. (Anne, 2011, p. 6)

Translation should give also to Wolof speakers and readers a chance to experience what the classic 
German poets were like. It is seen as a medium of understanding between people from different cultures, as a form of representation of foreign cultures, to talk with Doris Bachmann-Medick as suggested in the title of one of his famous works on theoretical issues related to translation Übersetzung als Repräsentation fremder Kulturen (Bachmann-Medick, 1997). Johann Wolfgang von Goethe was one of those who wanted to get rid of the notion of "national literature" to recommend the advent of world literature:

"National literature does not mean much at present, it is time for the era of world literature and everybody must endeavour to accelerate this epoch" ("Nationalliteratur will jetzt nicht viel sagen, die Epoche der Weltliteratur ist an der Zeit, und jeder muß jetzt dazu wirken, diese Epoche zu beschleunigen”) (Eckermann 198, 31 January 1827). (Birus, 2000, p. 8)

Regardless of the issue of reception, translation into African languages can be considered as a way to develop and to enrich African languages.

Un tel développement des langues est inséparable de la traduction d’ouvrages étrangers de toutes sortes (poésie, chant, roman, pièce de théâtre, ouvrages de philosophie, de mathématiques, de science, d’histoire. (Samb, 1992, p. 126)

This is the paraphrased idea of one of the most important defenders of African languages who recommends introducing terms and modes of expressions in the African languages that enable to render scientific and philosophical ideas (Samb, 1992, p. 123). Translation appears then as means to enrich ones languages. Far from the idea that translation is impossible, and people should give up and invest in learning foreign languages instead, (a thought attributed to Francis Bacon and Schopenhauer, edited by Herbert Ernst Wiegand, p. 93), the transfer between languages as it is operated though translation is a good way of self-enrichment.

\section{Conclusion}

In this article, the question of the translation of German poetry into Wolof was addressed. The analysis detected some borrowings and paraphrases as translation procedures. These enable to render faithfully some features of the selected German poems and to enrich the target language as well.

The translation makes it possible to give the Wolophon reader an access to epochal specific themes like tolerance or nature as very outstanding features of the German classicism.

Some particularities and differences could be noticed which are due to the geographic, temporal as well as cultural distances between the source text and the target text. As some examples illustrated, sometimes, the translation is very close to the epoch in which the texts have been produced.

Despite the difficulties of translating African poetry into German identified in this article, we can therefore say that in terms of reception the translation of the poems enables getting to know and appreciate German literature and stylistic as well as cultural features that are linked to it.

\section{References}

Anne, T. (2011). Téere-Woy yi/ Das Buch der Lieder. Jukkib-tànneefu woy yu ñu tekke ci Almaa: Goethe, Heine, Brecht ak ñeneen ak ñeneen. Eine Auswahl klassischer deutscher Dichter: Goethe, Heine, Brecht und andere. Übersetzung und Nachdichtung (Selected German poems of the classicism): Kulturbildverlag Markus Hoeft, Fredersdor.

Bachmann-Medick, D. (1997). Übersetzung als Repräsentation fremder Kulturen (Translation as representation of foreign cultures). Berlin: Erich Schmidt Verlag.

Berman, A. (2008). L'âge de la traduction: "La tâche du traducteur de Walter Benjamin, uncommentaire” (The era of translation. The task of the translator, a comment). Vincennes: Presses universitaires de Vincennes. 
Birus, H. (2000). The Goethean concept of world literature and comparative literature. CLCWeb: Comparative Literature and Culture.

Greiner, N. (2004). Übersetzung und Literaturwissenschaft (Translation and literature sciences). Tübingen: Gunter Narr Verlag.

Hermans, T., \& Koller, W. (2004). The relationship between translations and their sources, and the ontological status of translation. In H. E. Wiegand, Handbücher zur Sprach und Kommunikationswissenschaft. Handbooks of Linguistics and Communication Science.Manuels de linguistique et des sciences de communication (volume 26.1, pp. 23-31). S. Hugo (Ed.), Berlin· New York: Walter de Gruyter.

Lederer, M. (1994). La traduction aujourd'hui (translation nowadays). Paris: Hachette-Livre.

Neubert, A. (2002). Translation in Context: The cultural aspect. In T. Gisela et al. (Eds.), Kultur und Übersetzung. Methologische Probleme des Kulturtransfers (Culture and translation. Methodological problems of the cultural transfer) (pp. 227-241, 346). Tübingen: Gunter Narr Verlag.

Samb, D. (1992). Cheikh Anta Diop par Djibril Samb (Cheikh Anta Diop by Djibril Samb). Dakar: Les Nouvelles Editions Africaines du Sénégal.

Schleiermacher. (1963). Methoden des Übersetzens (Methods of translation). In Hans Joachim Störig (Ed.), Das Problem des Übersetzens (The problem of translation) (pp. 38-70). Stuttgart: Henry Goverts.

Top 10 sights and attractions in Germany. (22nd November 2012). Retrieved 15 ${ }^{\text {th }}$ October 2016 from http://www.wanderlust.co.uk/planatrip/inspire-me/lists/top-10-sights-and-attractions-in-germany

Wiegand, H. E. (2004). Handbücher zur Sprach- und Kommunikationswissenschaft. Handbooks of Linguistics and Communication Science. Manuels de linguistique et des sciences de communication (Vol. 26. 1). S. Hugo, (Ed.). Berlin, New York: Walter de Gruyter.

Zakhir, M. (2008). Translation procedures. Retrieved from http://www.translationdirectory.com/articles/article1704.php 